Research Paper

\title{
Metamorphoses Creative-Developmental Fairy Tale Therapy Against the Dangers of the Internet. A Series of Activities for Young Undergraduate Students
}

\author{
Irén Godó ${ }^{1}$ \\ Recommended citation: \\ Godó, I. (2021). Metamorphoses creative-developmental fairy tale therapy against the dangers of the internet. A series of \\ activities for young undergraduate students. Central European Journal of Educational Research, 3(3), 83-100. \\ https://doi.org/10.37441/cejer/2021/3/3/10144
}

\begin{abstract}
This paper is about the practical application of Metamorphoses creative-developmental fairy tale therapy, which is presented based on a three-session Metamorphoses creative-developmental fairy tale therapy session. The sessions were conducted between April and May 2021, among students $(n=24)$ of the University of Debrecen, who were previously not familiar with fairy tale therapy, nor with the works of Ildikó Boldizsár. Through the media environment of the session, we also reflected together on the effects of internet consumption and the dangers of the internet. The study highlights the students' attitudes towards this method and their participation and activity in the online space. The experiences gained during the 3 sessions and the feedback of the students appear as a guideline to conclude the study. The practical application of the Metamorphoses creative-developmental fairy tale therapy will show whether this methodology has a role to play in higher education.
\end{abstract}

Keywords: fairy tale; folk tale; literary fairy tale; creative-developmental fairy tale therapy; progressive education; undergraduate students

\section{Introduction}

The subject of this study is a fairy tale, which serves as a good foundation for progress during the pandemic that can refresh and entertain us. Ildikó Boldizsár's work can point the way to understanding the developmental impact of fairy tales, as her Metamorphoses creative-developmental fairy tale therapy training program uncovers new ways to reinterpret a person's processing of fairy tales. This knowledge is presented in the following modules: 'Creative-Developmental Fairy Tale Therapy', 'Self-Knowledge Through Tales', 'The use of Classical and Contemporary Fairy Tales in Fairy Tale Therapy', 'Individual Development Through Fairy Tales'. The Metamorphoses training aims to help us understand fairy tales as more than just external texts. This training exposes the different life situations bound up in fairy tales and helps us process the stories we relate to using self-evaluation. Becoming more self-aware is a very detailed procedure, thus qualified fairy tale therapists are needed to give professional help. With their guidance, much can be gleaned from tales. To avoid quackery or malpractice, only those with a tertiary degree are allowed to lead the creative-developmental fairy tale therapy training.

This paper presents the experiences of a three-week Metamorphoses creative story-therapy course for university students, on the topic of the internet. This a subject is deserving of more attention, especially regarding Generation $\mathrm{Y}$ and $\mathrm{Z}$, because though someone might know how to use the internet, they might not be consciously and carefully using it. Determining whether online information is true or not is a problem even for many adults. It is because of this and other self-awareness factors that also plague adults that we believe it

${ }^{1}$ Babeș-Bolyai University, Cluj-Napoca, Romania; krevippe@gmail.com This paper is a shortened, revised version of my thesis written in 2021 for the MA in Hungarian Language and Literature at Babeș-Bolyai University. 
essential to focus on the dangers of the internet. The three development sessions of the course included both original folktales and literary fairy tales. Though the net does not appear as directly (understandably) in folktales as in contemporary tales - for example, The Internet is Like a Puddle by Írisz Agócs and Innes Shona (translated by Dániel Varró) -, these folktales can also contain knowledge to help recognize and avoid the perils of the Internet (thinking, behavior, attitude, raising awareness, vigilance etc.). Therefore, going through this training can also serve a preventive purpose.

\section{The Internet as a Potential Source of Danger}

\section{Digitalization, the internet, and data}

In contemporary modern society, place of birth does not clearly define who lives where and who interacts with whom. Modernization, digitalization, and the emergence of the internet are enabling distances to be bridged. Compared to earlier societies, a kind of pluralism appeared in both thinking and friendships, as people seem to have a wider range of acquaintances, thanks in part to the ease of contact. However, one might have many acquaintances but few quality friendships. The internet does not improve on this either. It can be used to supplement and replace personal, face-to-face communication, i.e. you talk to someone either instead of or in addition to (but not parallel with) face-to-face communication. So distance is no barrier to information exchange in the $21^{\text {st }}$ century. However, because of a lack of personal communication we misjudge someone or fail to adequately get to know them. The abundance of information on the web can not only be productive but also counterproductive, as it is difficult to keep up with the increasing amount of data and information appearing in more and more places, it is challenging to keep track of everything, and it is arduous to identify true information (Mérö, 2019). Previously, the values and norms of the community positioned one's role in society, allowing one to decide what was right and wrong. In a growing flood of information, this is increasingly difficult. Lack of transparency and clarity leads to uncertainty and a crisis of values (Beck, 1999). Eurostat's (2020) data also showed that $81 \%$ of young people aged 16-19 in Hungary used the internet daily in 2011, increasing to $97 \%$ in 2019. Eurostat's 2016 survey showed that more than $90 \%$ of 16-24-year-olds use the internet at least once a week, and among the highly qualified, over $90 \%$ used the internet every week. By 2020, the number of mobile internet subscriptions in Hungary was 7.1 million, according to the HCSO (Hungarian Central Statistical Office), with 7.2 million subscriptions on wireless networks, 3.1 million on fixed networks, and 1.5 million on cable TV networks (Eurostat, 2020).

After computers, the internet emerged in the 1990s as a global network of interconnected computers, making broadband internet access a reality (Giddens, 2008). The big data phenomenon has grown out of the dramatically increasing amount of digital data, which researchers believe is growing exponentially over time (Dessewffy, 2019).

\section{Digital Space and Trust}

Presence on social media is also problematic because of the high level of intentionally misleading information. For example, fake user profiles can occur on social networking sites due to the presence of unverified members: for example, in the first three months of 2018, Facebook removed 583 million fake profiles from the site (Hern et al., 2018). The showcasing and selling out of privacy for the fame generated by social media is common. New types of influencers with celebrity status can be seen as products of social media, trying to gain popularity and influence through platforms such as YouTube, Facebook, TikTok, and Instagram. The path to fame has been made much easier by digital communication, where the cost/threshold of entry is extremely low and accessible to the masses. In this way, digital communication has tended to reinforce, democratize and expand the previously centralized interest and attention of the consumer masses, which is essential for building a reputation (Jenkins, 2006). In the pre-internet era, aggregates were only available to track findings, organized and referenced data published by scientists. In turn, digitalization and the internet have made it possible to express opinions and gossip online, hold political debates, make purchases and bets, make friends, and to upload other digital imprints and data about a person. Thanks to tech companies like Google, these things can be preserved in various databases or databanks. These imprints are always uploaded, shared, and left behind by users. Social sciences can also benefit from different digital imprints, as they make it possible to deconstruct holistic and homogeneous social concepts. This means that the various broad and abstract meanings of concepts that we often take for granted in everyday language (e.g. consumer, woman etc.) obscure the many diverse and varied systems of relationships and complexities, that these concepts and the networks of 
individuals behind them actually conceal (Latour, 2010). Unfortunately, because of their longevity, digital imprints can have a much stronger impact on an individual's social perception and esteem than earlier media products. On the one hand, individual responsibility has increased enormously, as the compromising content can be produced by the individual himself. On the other hand, a person's "digital footprint" can be easily and accurately retrieved by almost anyone, even decades later. Therefore, long forgotten opposing or unpopular opinions and statements can even after decades be "reheated" and can become once more the focus of public attention. The danger of this is, it might very well prevent someone from changing their character or may prevent the development of a worldview. Digital imprints project a negative image of us without faithfully reflecting the emotion and impulse behind our opinions. This puts young, rebellious teenagers who are seeking their identities as great risk. The double-edged sword of granularity also offers more opportunities than ever to map the individual's relationship system. More effective policing to detect anti-social, criminogenic networks is certainly good for public safety, but it also makes the innocent, law-abiding citizen much easier to observe and profile by all kinds of powers - be it the power of oligopoly giants or the state. Online, sensationalist, defamatory content is also preserved as a digital imprint. Indeed, there may be more opportunity, time, and space to make (press) corrections, if there is a demand for it (Dessewffy, 2019). The next defining phenomenon is the so-called "shared trust" (Botsman, 2019). Shared trust has emerged as a new form of trust, alongside the former (local) and institutional (mediated) trust. In the past, everyone knew everyone locally. Later, thanks to the trust that technology has built up between people, it has expanded into an important factor in economic and public life for everyone. Still in its early stages of development, it can help us to trust and use the various advanced technological systems and softwares that allow us to order, shop, and even get an overview of our medical condition. According to Botsman (2019), it is not primarily the technology that may shape our emerging understanding of the new form of trust being discussed, but the way and the extent to which trusts at large are changing. By appearing on the various social platforms and sharing our data, we trust the technological system, and this trust in the unknown creates different possibilities. It can lead to new relationships, and give us a sense of freedom, since the internet is yet informal less regulated than the physical reality outside of it. Another important conceptual element of this new form of trust is that we often trust strangers online without any guarantees or assurances (Botsman, 2019). Many malevolent people can abuse this new trust, causing emotional trauma and frustration (Tari, 2019). The development of young people's personalities and self-image is greatly influenced by the often malicious and toxic reactions they receive from others on the internet, which can be fatal for their self-esteem and personality development. Oftentimes, they are often forced into roles that do not fit their personalities - "it's not them" (Tari, 2019). The last line of comtemporary poet Tímea Turi's work \#privatelife, "I exist independently of myself," describes this self-alienated persona shaped by the internet. (Turi, 2020: 20) In the world of free commenting, proper moderation is not universal, so it is very easy for young people to spread their wings in an unsafe environment devoid of civilized and nonviolent communication. Because someone can be anonymous online and there is no physical contact with others, many people become belittling, aggressive and disrespectful even to the most basic human dignity. The chance to express negative sentiments online, usually without sanctions, is enormous. Still, on more sophisticated and serious platforms, some are trying to rectify the situation both through legislation and moderation (Tari, 2010). Here, we would like to refer back to the earlier interactionist theory, suggesting that we will react according to the actions of the other person. The lack of personal presence on the Internet limits response, so rudeness, disrespect, and aggression have much milder consequences than when confronted face-to-face (Tari, 2010). Of course, it is not unprecedented for defamation or an insult in the virtual world to turn into assault, civil action, or private prosecution in the real world. With these points in mind, I would like to respond to the dangers of the Internet within the context of university education, and to address how to avoid them. For this purpose, a 3-session course of Ildikó Boldizsár's (2019) Metamorphoses creative-developmental fairy tale therapy was conducted with higher educational students.

\section{Creative-Developmental Fairy Tale therapy as an Alternative Method}

The main trends in progressive educational thinking emerged in relation to children 3-6 years of age (Montessori, 1912; Steiner, 1995). Progressive education is a movement that emerged in the 1880s and developed at the turn of the century, which sought to renew pedagogical thinking and practice in a child-centered way. The main values of the new trend were freedom and self-government of children, and in its tools, it centered around group work, work-based learning, and project-based learning as timeless values (Dahlin, 2017). Progressive educational approaches typically appear only in preschool or in primary and secondary education. 
Different methodological elements are introduced with different emphases in education and teaching. Fairy tales are prominent not only in preschool but also in primary education. For example, students read folk tales and literary fairy tales in the lower grades, as well as fairy tale poems and children's novels (e.g. Vuk, Winnie the Pooh etc.), and children also work with Bible stories in age-appropriate formats. In secondary education, novels (novels in verse) and short stories containing more fictional and fantastic elements are taking the place of fairy tales (e.g. Csongor and Tünde, Gulliver's Travels The Golden Pot etc.). However, in higher education, both fairy tales and stories with fictional and fantastic elements are used only very occasionally and in specific situations (in nursery education, Hungarian language, and literature, ethnography, specialized literary therapy courses etc.). But the point of fairy tales is that we can reflect on them in certain situations in our lives, and they have something to say that we can utilize in the present or for the future. These help us define our own position and identity as a point of reflection (Boldizsár, 2019). Defining our position also means learning from the lessons of history. An undoubted advantage of progressive educational methods is that, while focusing on the integration of pupils into the education system, they have developed a range of methodologies and tools that can also effectively prevent drop-out. After the emergence of progressive educational trends, more and more alternative development methods came into being - Metamorphoses creative-developmental fairy tale therapy being one. Even before the appearance and application of these trends, the tradition of narration and storytelling were used to teach. Traditional storytelling communities have passed down traditions and knowledge through the ritual of storytelling, the latter becoming a very important community-building tool. Boldizsár attempts to revive this ancient ritual in her methodology (2019), using those elements that facilitate hearing the story and understanding the lessons it contains.

\section{The Metamorphoses Creative-Developmental Fairy Tale Therapy}

According to Ildikó Boldizsár (2013), the ability to understand the messages encoded in the stories has been forgotten, therefore, the need for professionals in the Metamorphoses creative-developmental storytelling therapy is urgent. Having a mediator between story and hearer is also critical. Metamorphoses' storytelling professionals are trained to help people understand fairy tales, all the while struggling to grasp them themselves. During this process, they gain skills from telling different types of tales. This requires much reading, where the stories are interpreted at the deepest possible level. Boldizsár's story-guide method (2013) helps reveal the path more easily, and understand the story more profoundly, unmasking the focus of the story and the area of life where it can be applied. It also teaches a new way of thinking. She urges storytellers to utilize this method to process as many stories as possible, since each of the tales could be useful for their future work. This is particularly important because, while students elaborate on the answers to questions, they themselves reflect on a story and develop a deeper connection with it. The symbols in the stories are not easy to translate from narrative tongue into vernacular language. Thus, to understand fairy tales people must pay attention to the events of their own lives (relying on their self-knowledge and emotions for interpretation) rather than come up with explanations. This is how a story can be truly immersive. The method is therefore distinct from the interpretation of a fairy tale, in which an "objective" reading of the tale is presented. In Ildikó Boldizsár's training, students create both objective and subjective story matrixes, to grasp the interpretation of both story matrixes (Boldizsár, 2013). Working with both can be effective in this therapy, for, a story might be very jam-packed with content. For example, some stories direct a person to seek and come up with adequate answers to the changes around us in life - regardless of whether they are physical or mental changes. "Every fairy tale is an imprint of a human experience, but even if we knew all the fairy tales in the world, we still could not say that we now know, how the world works in its entirety." (Boldizsár, 2013: 28) Stories can show us where the stages of life begin and end, while making it apparent that somebody must first live through one stage's entire range of possibilities before progressing to the next stage. It is also made clear that we must move on from a completed stage, and that there is no need to get stuck out of fear or a sense of comfortability. Stories also aid us in recognizing the life challenges we may face as children, young people, adults, and elders. Tales encompass all life situations and thus harshly display us in front of a mirror (Boldizsár, 2013). Moreover, because we are not working primarily with the specific event, special emphasis is not placed on self-knowledge in relation to the stories, but rather on the feelings that accompany the event. One of the main theses Metamorphoses therapy training is that it is not the tale that heals the person, but the person's relationship to the tale (Boldizsár, 2019), i.e. listening to a story alone does not lead to listener development. The processual nature of working with a tale cannot be denied. It can also happen that a fairy tale still works within us months or even years after the creativedevelopmental storytelling session. Boldizsár (2019) debunks the misconception that everything in fairy tales 
is good and beautiful, instead emphasizing that order in fairy tales is not a given, everything has to be worked for (Boldizsár, 2019). However, in some cases it is not even easy to define your own position in the world, therefore, in a fairy tale, settings can also help in the course of self-awareness work. Sometimes it is easier to place ourselves, to define our own position in a story than in the real world. This immersion into the story, this hermeneutical way of thinking about the story's plot elements can help us with self-reflection. Of course, this does not mean that we are cut off from the real world. On the contrary, through the story we can understand ourselves, which can help us to understand our actions and reflect on them, to recognize our motives, and to determine our path and purpose for the future (Boldizsár, 2019). Boldizsár (2019) also confirms that clients opened up more easily by hiding behind a fairy tale character than by talking about themselves directly in the first-person singular.

\section{The Developmental Impact of Fairy Tales in the Metamorphoses Creative-Developmental Fairy Tale Therapy}

Fairy tale therapy is a type of bibliotherapy. In 1988, a catalog of Hungarian folk tales was compiled in Hungary, which distinguishes 71 versions and has been continuously updated since. There are also variations of tale types, 2000 of which are highlighted by the catalog of international tale types (Boldizsár, 2019, and based on the Metamorphoses creative-developmental story therapy course notes). The European tale treasury consists of 9 tale genres (fable, magic or fairy tales, legends, short stories, dark devil tales, mocking tales, joke tales, liar's tales, and formula tales.

The fable illustrates some moral truth, some wisdom for life. In fables, the human behavior of animals is not a miraculous element. The characteristics make this type of story picturesque. Decisive situations feature prominently in these stories, usually with no 3 options to try and no helper. Animal stories can help us break with our habitual patterns, and can provide for us to reflect on our mistakes, while also relieving anxiety and fear. Finding personal application is also very easy. (e.g. I am a raven or a fox). This type of story can be used to interpret a situation from multiple perspectives (Boldizsár, 2019). In fairy tales (magical tales) the scenarios of the order are complete, all the steps are included in the tales. Fairy tales provide actionable patterns of behavior in order to cope with every situation in life. Within fairy tales, we must also touch on the various character types existent. Propp (2005) distinguishes 7 major characters in fairy tales: a hero, a villain, a helper, and a party of the opposite sex are always included in these tales. A false hero, a sojourner, and a benefactor are also written in. Although, it is the relationship between the 7 characters that determines the story's ending (Boldizsár, 2019, and based on the notes of the Metamorphoses creative-developmental fairy tale therapy training). As far as legends go, there are 3 major examples to look at: the origin story (e.g. How did God Create the Gypsy Man?), St. Peter and Christ wandering the earth (exposing people to various trials and punishing or rewarding them accordingly), and St. Peter ruling over creation (e.g. Walnut Tree and Pumpkin). These stories can be used to reinforce conscious behavior. They can remind us of the way the world works, and solidify our sense of responsibility for our own moral actions. In short stories, there are usually no miraculous elements. They take place in the this-worldly setting, with this-worldly characters. This includes ingenious tales, tales that show the depth of presence in the world (e.g. clever women). Compared to the other fairy tale types, in this type, women are more likely to be challenged (a woman's thinking is challenged, for example). These can strengthen a person's conscious grasp on the world, his connection to it, and his sensory functions with which he detects and understands the outside world (Boldizsár, 2019, and based on the notes of Metamorphoses creative-developmental fairy tale therapy training). In dark devil tales, opponents appear that cannot be defeated by force. These reveal those opposing forces as parts of this world's order. Rather than defeating them, you get into a proper relationship with them. In creative-developmental fairy tale therapy, these stories are mostly used to treat addictions. The main character is usually helped by a close, blood relative. Mocking tales used to be told during seasonal work or even during military service. This includes so-called „csujjogattó” (chatter) tales. Their central theme was not to hurt someone but to display togetherness. These stories usually focused on the storyteller, portraying a character at which everyone could laugh. In addition to entertainment/amusement, this type of story could also be used to manage anger and channel aggression. Joke tales have a tension-reducing role. In these, often negative examples are brought forth to show what would be desirable. There is no order in this type of tale, it is often grotesque, and the lack of a happy ending allows for discussion and provision of one. Liar's tales activate the brain's right hemisphere. Logical thinking does not prevail. In this type, the impossible remains impossible and becomes a source of humor. The aim can be to distract and refresh the soul. Formula tales can include decoy tales, sound imitation tales, and chain tales (e.g. The Ant and the Snow, The Cursed Piping Hen etc.). We can see patterns of aggregation in these short stories. They can help to develop planned 
thinking, understanding of cause and effect, control of impulses and emotions, and even help psychologists in individual story therapy to treat patients with panic disorders (Boldizsár, 2019, and based on the notes of Metamorphoses creative-developmental fairy tale therapy training).

In bibliotherapy, tales can be used in a variety of ways:

1. creation tales: here we are working with the idea that somebody somehow creates something for some reason

2. as mirrors and role models

3. as open-ended, unfinished works, in which it is possible to start, finish, and continue a story according to a person's own reality or liking

4. as counter-pattern creators: that an individual is challenged to follow throughout the story

5. as a creator's canvas: allowing persons to access their creative energies, and release them - a self-healing process.

The protagonist's development starts with leaving his comfort zone, either because he himself has a purpose, or because he is sent or even driven away from home (Kádár, 2014). Both Kádár (2014) and Boldizsár (2019) emphasize that every character in a fairy tale reflects the storyteller and/or hearer himself/herself. At first, one always understands a fairy tale from an external point of view, but later one realizes that all the characters in the fairy tale point to him/her (Boldizsár, 2019). Not only that, but the listener is, after all, in the subconscious, and the locations and the codes of action there play a key role in his/her development. It is for these reasons, Boldizsár (2019) works only with folktales in individual development based on the method she developed.

\section{The Healing Effect of Fairy Tales in the Metamorphoses Creative-Developmental Fairy Tale Therapy}

Storytelling is more than prose. It is the conveyance of knowledge and information, the reminder of an important truth, the guide to emotional liberation and finding one's inner voice, activation of the subconscious. In oral storytelling, the first and most important benefit of story is that the narrator can completely calm the audience, relieve tension and anxiety. "In the fairy tale, man is a statue of himself and the infinite possibilities of himself." (Nagy, 1974: 18)

Through suggestion, the story can elicit speech from the listener and evoke involuntary responses as well (Boldizsár, 2019):

- $\quad$ illuminating a previously hidden area within the listener (this is not conscious)

- causing long-suppressed feelings to finally surface

- activating passive life energies and generating various emotions, on which the creative-developmental fairy tale therapy sessions can be based

- $\quad$ extracting important information from the subconscious

- $\quad$ putting a problem into a new framework (based on Boldizsár's training note)

A listening trance is created when listening to folktales. With folktales, the storyteller has to crack the code, attributing to him greater responsibility. It usually touches everyone in some way through collective subconscious. Psychologically true situations come to life in folktales. The focus of attention is intense, the body inactive, the brain very busy. When a narrator performs a listening trance, the words used act as a brush to paint with, the storyteller sending pictures, and the pictures can be turned back into words. Visual imaginative synchronicity describes the phenomenon where what storytellers say and what the audience hears are the same. In hypnosis, there are all sorts of techniques to induce a state of special an altered consciousness. Fairy tales can do the same. The tale is homogenizing and calming, so it's a good idea to stimulate the mind before listening to it. In the case of literary fairy tales, the fairy tale therapists are able to better influence where the mental focus is, depending on where the narrative arc is taken than in folktales. The subconscious, however, in this form remains untouched. Relying less on feelings, the fairy tale therapist uses bibliotherapeutic tools to draw the arc of thinking about the story. The literary fairy tales also present concrete situations for children, to help them get the stories' main points. Again, in this form, there is catharsis. This is what we can work on within creativedevelopmental fairy tale therapy sessions using this type of tale. By working with literary fairy tales, we quiet the mind, make space for the personal through physical work. Stories stir the imagination and develop creative thinking (Mezö, 2017). Imagination and fantasy are not the same, though. Imagination is reproductive (imagining what we already know, what we already have), fantasy is productive, allowing us to create what doesn't exist yet. The imagination must be trained to develop fantasy. At the same time, fairy tales can be a 
basis for self-knowledge, they can teach us how to find our inner state in other words, serve as a mirror. They develop emotional intelligence (recognizing and naming one's own and others' emotions and helping to relate and connect to them appropriately). They can also serve as a model for behavior and thinking, as stories show what the optimal behavior would be in a given situation, and therefore can serve as a compass and a means of identification. Life strategies also exist in stories, and there are many puzzles to solve. Each story points to the need for progress.

The stories create patterns of connection at 4 levels:

1. connection to ourselves

2. connection to others

3. connecting with communities

4. connection to the invisible world (channeling into an ancient sacred communication system in folktales)

\section{The Folktale and the Literary Fairy Tale from the Point of View of Metamorphoses Therapy}

The following table illustrates the characteristics, similarities, and differences between folktales and literary fairy tales:

The similarity between the two types of stories is that the heroes typically have a special mission or task. Development and progress are important in both types of tales. The term "literary" sometimes means that what is literary is not an expression of the natural storytelling mood of people. If we use the word "artistic", we can also think of a high degree of artistic sophistication in fiction and the use of a conscious narrative technique. While transmission of folktales is characterized by oral tradition, literary tales are passed down via reading to an audience of listeners or through the audience doing the reading actively. The values of the folktales are the same as those of the community that keeps the tale alive, while the worldview of the literary tales is more skeptical. Literary tales do not only contain children's stories. The journey in a story usually causes a change in the lives of the characters. Topics may include things related to the functioning and understanding of life, normative crises, the truths of life. In folktales the homogeneous and unified worldview helps us to find our way around, while in fictional tales we can find chaotic and cluttered worldviews. In the folk tale, the basic questions of human existence (f.e. birth, death, grief, groving up, relationships, etc.) usually appear as themes, whereas in literary tales, much more differentiated detailed themes (e.g., teething, internet use etc.) occur. Thus, they are more difficult to apply to everyday life. On the upside, there are many situations familiar to children in this form. In fiction, there are fewer big heroes and big goals, the solution is not important, you can be wrong, be bad, and even give up. There are little to no trials, often no helpers, no magic elements, no rules. The false heroes win regularly, the real ones are lonely on a regular basis. Varied games and toys can also be found within this tale type. According to Timárné Hunya (2006), who has examined differences with magical tales as well, it is important for literature studies to examine both folktales and literary fairy tales as literary works. She claims that by finding the common and divergent points of the two, we can get closer to understanding fairy tales as a whole. If someone identifies and sympathizes with the hero of the folktale, it creates a sense of safety in the person, because the hero is likely to succeed (Timárné Hunya, 2006). In the case of literary fairy tales, the plot is more complex, and the emphasis is on overcoming difficulties. In folk tales, the goal is concrete, linked to individual happiness and material well-being. Literary fairy tale plots may start off due to some internal compulsion (crisis, wish, desire). It is possible that the inner compulsion, the gap at the end of the fairy tale cannot be filled, making the end of the fairy tale melancholy. While the hero is on the road, he discovers himself - the mysteries of the soul, the meaning of life. It may not be a specific goal, but perhaps an ideal goal. The characteristics and personalities of the characters in fictional tales are generally more complex than in folk tales. The folktale is not bound by space and time, nor is it linked to a specific problem, i.e. folk tales are characterized by the timeless-nameless scheme. Emphasis is on the action. Its language is simpler, more concise, in contrast to the richly ornamented language of literary fairy tales, which are usually dominated by text. A literary fairy tale reflects its author's personality (Timárné Hunya, 2006). "Fairy tales show the sublimated essence of reality." (Timárné, Hunya, 2006: 131). All in all, tales can prepare us for the good and the bad, and the joyful and the tragic events in life. And if someone has already heard a story, it can give a sense of safety to hear it again. When someone has been buffeted by life's hardships, they can learn coping patterns from the stories. 


\section{The Sessions and Experiences of Metamorphoses Creative-Development Storytelling Therapy}

\section{The Circumstances of the Developement-Research Method}

Undergraduate university students seemed to be the best pick for this project because: 1) they needed no parental consent to cooperate in the sessions, and 2) they were best equipped for online sessions. The training took place as a university course in April and May 2021 in three 2,5-2,75 hour blocks (one session every week for three weeks), on three different days. The total number of participants was 24 , but usually 14-18 people attended each session. The vast majority of the Hungarian university students who participated in the sessions were oriented towards the field of humanities (16 person), although a smaller number (8 person) were studying other fields (sciences, pharmaceutical sciences). From here on out, we will refer to the above-mentioned faculties by their Hungarian abbreviations, i.e. faculty of humanities will be referred as BTK, faculty of sciences as TTK and faculty of pharmaceutical sciences as GYTK. We worked with the lecturer's Zoom program, who helped us by taking notes. She felt that the sessions could be integrated into her syllabus (she wanted to illustrate to the students the characteristics of the Metamorphoses creative-developmental storytelling session), so she managed to implement the creative-developmental storytelling sessions with a dual purpose: to demonstrate the method and to explore the scientific research. The students who participated in the sessions consented to anonymously publish the sentences, thoughts, stories, posters, and pictures in the study. The program's realization was driven by a number of questions: 1) whether this particular pedagogical method could be applied to the online platform; 2) whether there was any place for progressive educational methods in higher education, regardless of their form (online or offline); 3) what the force might be that is hindering the emergence and spread of this method in our Hungarian universities and colleges; 4) why this has only been the "privilege" of primary and secondary school students; 5) whether it is most efficient to use the online platform to make an impact or to cling to the face-to-face option. As a topic, dealing with the dangers of the internet will also be a great help in shaping and developing this approach.

\section{The Course of the Sessions}

The creative-developmental fairy tale therapy focused on the conscious use of fairy tales in the context of the dangers of the internet, focusing on the demonstration of Metamorphoses creative-developmental storytelling. The processing of the stories was not based on textual understanding but on thought-provoking and creative exercises that helped the students to develop their skills, conscious Internet usage habits, abilities to recognize potential dangers, and more. The selected stories and exercises also addressed the importance of conscious presence on the internet, i.e. not only consciously posted content but also self-representation on the internet. The central ideas (trust, self-image, self-concept, self-representation, deception, and defense) were discussed and reflected on by the students, and in addition to the supporting role of the stories, they were able to respond to these themes in a self-reflective way in order to raise awareness of the dangers of the internet and to cope with them. For the last session, 17 students who participated in the session made a poster in group work about the dangers of the internet, capturing the aspects they considered important.

In building the plans for the session, following Ildikó Boldizsár (2019), it was important to give a channnce some kind of self-reflection on the tale. This provided an opportunity for self-awareness development. The processing of the stories started with an introduction and tuning in to the tale. In all cases, I tried to capture the personal level of the stories with targeted conversations at the very end of the sessions. I also attempted to address the Internet in terms of the development potential of stories. The age specificity of the students was also taken into account. In the following part, we will lay out the methodology of paper theatre, as it was used in one of the sessions.

\section{Paper Theatre}

The Japanese word kamishibai means "paper theatre" (kami: paper + shibai: theatre). This storytelling art form has been in use since 1820. Its essence is to turn a storybook into a theatrical experience. Pictures show the parts of a story while the narrator reads the text aloud. The images reinforce the text. The visual stimulus plays an important role in the thrilling and entertaining performance, making the story more accessible and gripping. Pictures can also be used to develop association, as the chain of events that do not appear in pictures is left to the imagination. The frame around the theatre also helps to focus audience attention. The magic of artistic images arranged in a row is not enough for the theatrical experience, however. The manner in which 
they are presented verbally also makes a difference. Here, both image and text work together in a paper theatre performance. Thus, it has an effect on visual memory, making the story itself easier to recall. The performer varies the momentum with which he or she moves the images and tells the story. Image manipulation techniques can add dynamism to illustrations, multiplying their impact and presenting it to the audience in a cartoon-like way. However, it is much more than a cartoon, as the performer can tailor the performance to the reactions of the audience through his or her personal presence. They can step out from behind the paper theatre or even stay there until the end of the performance. In case of the latter, he/she can react mainly to the verbal stimuli of the audience (e.g. with volume, playfulness, or even with a narrative utterance etc.). And if the performer can see the audience, his or her observations can also help to make the storytelling experience even more profound. After all, the storytellers of old also took the reactions of the community into account when they were (re)shaping their story-weaving and performance style. Applying paper theatre to today's internet-connected world, due to its multifaceted nature, it can focus children's attention to the maximum (Csányi et al., 2016). Metamorphoses creative-developmental fairy tale therapy is similar. Just like paper theatre, it employs a variety of tools and methods to facilitate the reception of fairy tales. Tools might be: a story, a song, a riddle, picture cards, or anything else that fits the theme of the session. It is important to note, these tools and methods are meant to enhance the reception of the story, not to obscure it or distract the audience's attention from it. In the methodological repertoire stands the paper theatre of Csimota Publishing, whose elaborately drawn visual world brings us closer to the story we hear (Boldizsár, 2019). It can also be applied to literary fairy tales, as the texts on the back of each picture are preserved in their original form. Out of respect for the writer, the stories in Metamorphoses therapy are told in verbatim, keeping faithful to the original text. This Metamorphoses method is made colorful and more attractive by the presence of paper theatre. Because paper theatre by its very nature visualizes the story, Boldizsár's (2019) method does not then give tasks to participants that involve visualizing the characters. Truth be told, they already did that during the performance. Paper theatre fully preserves the story's content, but due to its illustrations fantasy takes a back seat. The illustration arbitrarily and unintentionally highlights certain elements of the tale while we focus on what the illustration itself emphasizes. At the same time, the illustration helps the audience to keep the focus on the substance of the story. It neither shortens nor lengthens the duration of the storytime. However, a lot of work and preparation is required with paper theatre. It is important that everyone can see the pictures, thus care should be taken in picking the distance between the storyteller and the listener. Images themselves can be a special point for reflection, i.e. we can ask the listeners about their impressions of the images (or how those impressions differ from the pictures). This would help them work with the story. The colors and the mood of the images can also evoke feelings (Csányi et al., 2016).

\section{Experiences of Metamorphoses Creative-Developmental Fairy Tale Therapy Sessions}

The sessions showed that there is a place for a creative-developmental fairy tale therapy course online, and it was a refreshing addition to the usual teaching methods. I have received feedback on this from several people. And by working on the web, we have also been able to take advantage of all it has to offer (e.g. creating group rooms). The developmental impact of fairy tales can be understood from several aspects, as they have not only entertainment value but also a knowledge transfer function, at the same time, their impact on selfawareness and skills development is indisputable (Boldizsár, 2019). The messages contained in fairy tales can also serve as a benchmark for adults' own lives (Boldizsár, 2019). Our students involved in the experiment were able to respond to the internet-related topic in a general and reflexive way. Next, the experiences of the sessions will be presented in a narrative context reflecting the sessions' nature. In this way, we can also authentically portray the emotional state and mood of the students, which are confirmed by the things they said during the sessions. We consider it important to reflect their impressions faithfully because, on the one hand, the sessions are highly experiential and, on the other hand, our obvious agenda is to influence the emotional state and mood of the participants during the sessions, besides developing their awareness of Internet usage. It would be difficult to reflect the change or context of these in a less narrative-like way.

To focus on the dangers of the internet, 3 stories were used, which were typically developed in 2.5-2.75 hour sessions with undergraduate students:

1. occasion: The Wings of Lotilko (Tungusic folktale): trust

2. occasion: Hans Christian Andersen: The Ugly Duckling: self-image, self-concept, self-representation

3. occasion: The Wolf and the Seven Little Goats (folktale): deception and defense 
The First Session: the Metamorphoses Creative-Developmental Fairy Tale Therapy Session, Lotilko's Wings - Reflection

During the first session, introductions were made. Since the group already knew each other, we called each by their first names, and grabbed the students' attention by asking the question "How are you?" in an unusual way: "How is the weather inside?" (by Ildikó Boldizsár), which allowed the students to express their feelings in the form of a weather-related image. This helped tune them to the 3 sessions and prepped them to absorb the imagery in the stories. The sound of the Koshi as an auditory stimulus helped to sharpen the senses, which play an important role in listening to the story and in the session.

The proverbs and sayings about birds were intended to get the audience in the right mood. The same goes for the motif of flight, which stimulates movement. This was important because it was easy to take the listeners from accelerating and then decelerating movement into the story, introducing them to a realm where their senses would be really needed. Through live, oral storytelling online, imagination and fantasy were put to work. That is why the figure of Lotilko the center of questioning (how who imagines his character). This occasion was built around the processing of trust so that this thread was captured in the otherwise multi-faceted story. After Lotilko, the students were able to talk about trust in relation to themselves. As a result, we could learn about trust in a complex way. The following aspects were highlighted: trust should be earned; one should be able to count on the other at all times, in good times and bad; in front of the trusted partner it is important not to be ashamed to show that one is emotionally vulnerable; and they highlighted reciprocity/loaning devotion; straightforwardness, honesty; respect; loyalty; faith in the person; it was also noted that it feels good to tell a confidant something that you would not tell someone else without surety of the safety of that confidential information. It can take a long time to build trust, even one bit of disappointment can be enough to break it. To us, it was pleasing that, despite expecting a one-sentence response from listeners (many held true to this), a very nuanced, complex approach to trust emerged overall in response.

The maze game was enjoyed by several students having an easier mode and a harder one. The task was to find the way out of the maze (just like the lost Lotilko). After the slightly easier maze game, some students took on the other more difficult one. Differences in controls were also put in place - one was easier to control with the mouse, the other with arrow keys). During the game, the students could hear the Koshi. Some said: "I was kind of stunned, because I don't really do this kind of thing, but I did it so quickly that I was proud of myself" (1st time, 24th participant, female, TTK), and others who liked this kind of exercise and had done it a lot remarked: "I like this kind of thing, and I did it a lot when I was little." (1st time, 2nd participant, female, BTK) The exercise was generally well-received by participants. One student commented, "I like this kind of thing, something to think about, but I can enjoy it at the same time." (1st time, 5th participant, male, BTK)

Once out of the maze, the solution set the stage for the resourcing exercise, where we asked students about resources they had used during the game. After discussing the situation of Lotilko, the talk started on the dangers and pitfalls of the Internet. Later, in groups, the students came up with ideas and suggestions on how to use the internet more consciously. Finally, mentimeter.com was used to ask who has what resource (see Figure 1). Students were asked to list five resources, but they were not obliged to put down five. Some respondents also reported that they found the exercise useful from a self-awareness point of view. Overall, it can be said that the theme of trust was captured in a nuanced way, not only through Lotilko's story, but also in terms of online presence and behavior. The story also helped to develop self-awareness. The latter was evident in the feedback as well. One of the participants reported the following at the end of the day: "It was also very enlightening to think about it in this way, to think about myself, what my strengths are. It was a little bit of a puzzle for me to put together five of them, but in the end, I did it, so I really liked it." (1st time, 10th participant, female, BTK)

Another student commented, "I also really liked it and it was creative and instructive how much you can get out of such a short story and how many different tools and things you can illustrate." (1st time, 16th participant, female, TTK) 
Figure 1. Resources of the undergraduate students participating in the session. Source: classwork. The figure is published with the consent of the participating students. The language of the activity was Hungarian.

\section{What kind of resources do you have?}

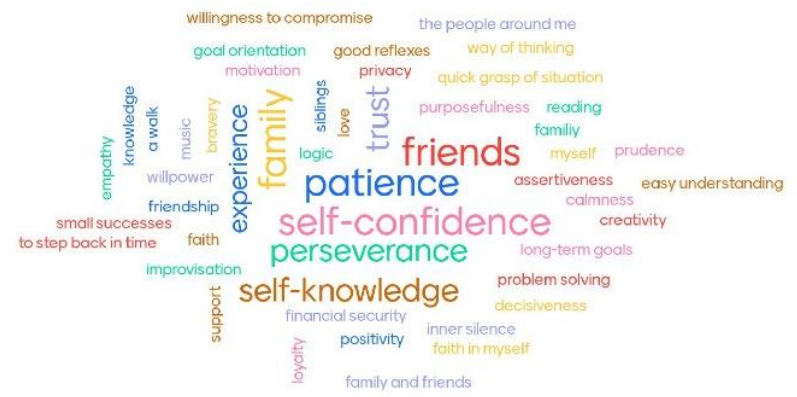

This is the English translation of the original wordcloud in Hungarian, based on and made from the thoughts of the participants. Figure is used with the consent of the participants. (edited by www.mentimeter.com)

The Second Session: Draft of the Second Metamorphoses Creative-Developmental Fairy Tale Therapy Session - The Ugly Duckling - Reflection

The theme of the ideal of beauty was included in the series of sessions because it was felt that many in the group were reflecting on the idea compliments. Some students reflected aloud. The group exercise not only helped to bring the group together and to get to know each other but also brought a sense of concentration. On the topic of the ideal of beauty, the main aspects that the groups were able to address were: the historical aspect (e.g. different beauty ideals in different times, shortening of skirts etc.), the relationship between beauty and health (morbid obesity - morbid thinness), the influence of social media and advertising, the influence of beauty and the market (e.g. fashion industry, modeling, actors and influencers etc.), femininity in the 21st century (girls maturing earlier, showing a lot of themselves on the internet etc.), subjectivity (how people see themselves) and expectations (how others see you) etc.

The story was familiar to many, but the paper theatre experience gave it a sense of novelty that helped it to be understood and enjoyed, and also to attract student attention. The experience of paper theatre was likened by many to a slide film. "I could compare it to that, it was kind of like when we used to have these projectors, and it was kind of like storytelling when you showed the pictures like that. They showed pictures like that. But it was very good, I really liked it." (2nd time, 23rd participant, female, BTK)

"I also had nostalgic experiences, and I also remembered when we had the slide show at our house, and then the pictures and the story. This fairy tale brings back such fond memories in me too." (2nd time,11th participant, female, BTK)

We then asked for an individual continuation of the story of the Ugly Duckling (from the moment it went out into the world) from the listeners, as many of them were familiar with the story and could have approached it in a unique way. For, the ending of the story reveals a lot about thoughts, emotions, and attitudes. Since the ugly duckling actually set off because he was ostracized for being ugly, I was curious to see what the listeners would do with this situation. It is well known that many people on the Internet fall victim to unsolicited comments, and we can see this in real life too. I also wanted to include the role of self-confidence and selfesteem among the issues raised during the session. The various intriguing endings really spoke volumes about those who narrated - about their thoughts and emotions. This exercise also helped in approaching the relationship between the story and the individual. Each end could even be used in individual story therapy. Due to lack of time, however, the whys of the endings could not be heard (that was not the goal on this occasion). The follow-up questions was: "What will you take away from today's session?" several of us gave feedback on the approach to the creative task. One commented at the end of the day, "For me, it was an interesting experience of self-praise. The alternative ending to the story worked too. It was actually one of the most fun tasks I had this week. So I enjoyed it." (2nd time, 22nd participant, male, GYTK) Most of the stories ended on a positive note, but there were 2 cases where the end closed in a sad way:

"Because of all the abuse, he didn't have the confidence or the self-confidence to create a positive enough image of himself, and so he thought he couldn't be a full member of society, of any society, and so he preferred to live in solitude." (2nd time, 2nd participant, female, BTK) 
"I was also thinking of a pessimistic ending. My ugly duckling would go home and sadly resign himself to not being adopted and try to fit in with the ducks. Sad, sitting on the beach." (2nd time, 17th participant, female, BTK)

Many positive stories could be highlighted, and the examples below illustrate that there is much in stories that can be used in story therapy:

"The duckling goes out intending to find a community, a family, where he will be accepted with all his ugliness and whether he is smart or dumb, whether he swims well or not. But on his journey, he does not find a community where he is accepted. Everywhere he is judged and he feels he misses his original family, the original community where he was. So he returns home to his mother and siblings. But when he arrives, he finds that they look at him with admiration, faces drenched in admiration. But when she gets down to the water she sees that she has become a beautiful swan, and now she realizes that this is why she was ugly, because to be beautiful she first has to be ugly. And in the meantime, her companions will get to know her, her inner qualities, and they will no longer judge her and love her. And everyone apologizes to her, and she forgives everyone, and so eventually the other ducks realize that they can't just judge others. So it is engraved on their minds forever that they shouldn't judge other people, and that's how they end up living happily as a weird little community." (2nd time, 18th participant, female, BTK)

"The ugly duckling has given up self-flagellation and decided to go out into the world. This opened up a world of opportunities. He traveled to far-flung countries and immersed himself in music, languages, literature, cinema, gastronomy, and many other arts. During his travels, he realized two things: that looks really mean very little and that no matter how hard you try, you can't please everyone. He came to a firm decision. He decided that instead of expecting others to do it, he would create the mental health needs necessary for his own satisfaction. He found a passion, took up the sport, attended training courses, and, although his journey was bumpy, he found his place in the world. In this way, unwillingly and effortlessly, he made many true friends. What is more, he met a lovely duckling who loved him for who he was. But that's another story." (2nd time, 1st participant, male, BTK)

"The ugly duckling goes out into the world and seeks out rejected, ostracized companions with whom he can form a so-called community of destiny. And they are the ones who support each other, accept each other, know how to relate to each other. And they will be the most tolerant small community, open to those who feel exiled and alone. And this small community is empowering. It doesn't let members suffer from self-esteem issues, and they fly the flag for a variety of humane values that are very important. Since then they have been at the forefront of empathy and acceptance. And it's a community that's open to everyone, by the way, and has forged itself into a real little community of love." (2nd time, 15 th participant, female, TTK)

On this occasion, the Koshi was also playing while the story was being written (those, who wanted to, could turn the sound off until it was finished).

The various endings can be arranged in the following order in terms of the position of the ugly duckling in the stories told:

- $\quad$ remained lonely

- $\quad$ found a companion who helped her to recognize her beauty, either by showing her beauty or by beginning to appreciate her or both

- $\quad$ went back to the community or did not go back

- found a new community or found a couple

In the end, we discussed what to pay attention to when presenting yourself on the internet. Answers included: background (how visible is the background (valuables, entrance etc.); how provocative is the picture (important in the context of online harassment); is there someone else in the picture (if there is someone else in the picture, if possible, ask permission to post the picture if you don't want to cut them out of it); content sharing appropriate to the workplace (e.g. not retouching a picture beyond recognition etc.) The session achieved its purpose, it was a good opportunity to go in-depth on the topic of online presence. 
Third Session: Draft of the Third Metamorphoses Creative-Developmental Fairy Tale Therapy Session - The Wolf and the Seven Little Goats - Reflection

After the question "What's the weather like inside?", there was a riddle question, which everyone could answer privately. Some people said the answer out loud in the first minute or two, so not everyone was able to think about the question for long.

After getting into the mood of the topic (since wolves and goats were included in the riddle, as they are in the story), we presented the motif of knocking to the listeners, which gave them an insight into the story. We could play with the sounds, some knocking louder, some knocking softer. Finally, they were given access to the realm of the story. By this time they knew the script and knew they were about to hear another story. They also learned that I was relying on them for attention and activity, as they had been given many thoughtprovoking tasks to do so far.

The students listed the senses that the wolf had to look for when deceiving the little goats. They mentioned hearing (in terms of tone of voice, calling) and sight (appearance). They emphasized the role of calling and being nice, which also gives the feeling that "we already know each other from somewhere and might be on good terms" (3rd time, 20th participant, female, GYTK). The wolf's role was not always the same, as it was easier for him to play a person who is important to the goats and whose word the goats hear and receive. The wolf in the story also knew that their mother had gone into the woods, so he knew the right time to attack the goats - when they were at home alone. The wolf also tried to use the power of gift-giving when approaching the little goats " -Open up, my darlings, it's me, your mother. I've brought you all something nice to eat!" (nepmese.hu) The motherly advice given to the kids by their mom before setting out was also emphasized. Attention and vigilance were important not only for the goat kids (to watch out for signs that might give away the fact that it was not their mother knocking at the door) but also for the wolf, who tried to be all the more thorough and deceptive until he won his prize.

From here, the manipulative catches of the wolf transferred to the manipulations of the internet. The nature of these was discussed in pairs, with a specific focus on how the incident could have been avoided. They could search the internet for stories of deception, or even bring their own or a friend's example into the discussion. A lot of aspects of internet dangers were covered (e.g. There were also different types of deceptive e-mails to try to trick people into giving you bank details or money, theft of data to offer you discounts, unrealistic stories about people who don't have a subscription being sent a mobile phone bill etc.)

Some groups used fairy tale examples of deception. The story of Snow White was used to illustrate deception by the evil stepmother. The group pointed to the witch's implausibility, which may be intended to evoke empathy and the fact that Snow White just gets an apple (especially as we don't just get things anymore). Another example that came up was Little Red Riding Hood and the Wolf, where Little Red Riding Hood saw the various warning signs, but still didn't become suspicious enough to uncover the truth. Parenting was also brought up by the students. They thought it important to emphasize the importance of parents not letting their children talk to strangers.

In one case, the students focused on the aspect of conscious internet use, focusing on the fact that not everyone is who they say they are. Naivety was emphasized. They also stressed the importance of constantly monitoring the time spent online. It was suggested that screen time should be checked, and that limits could even be set using certain applications. It was also reinforced that data should not be disclosed to anyone online (see the poster on Internet Awareness).

In the case of the poster/meme, the central idea was that not everything is what it seems, it is difficult to decide what is real and what is not online. One, strong focal idea was captured (see the poster "Not everything is what it seems").

It was considered important to be critical of the content published on the internet (who posted it, the source of the news, when exactly it was created etc.). The importance of getting information from a credible source was also highlighted. It was also mentioned that just because something is trendy or popular does not necessarily mean that it is an example to follow. Students pointed out that some challenges are particularly dangerous, and thus should be avoided. The protection of personal data was also discussed. During our time, we gathered that there were several facets of online threats that were important to be aware of. The Snapchat app was mentioned, where communication disappears. The title of their poster was also chosen as the motto for this dissertation: "More sense than trust!" (see the poster "The dangers of the internet - More sense than trust!")

There was also a poster/meme that tried to reflect on the Internet through human development. This group highlighted that it makes a big difference what we do with the internet, either something useful or something 
useless. They illustrated awareness by using a picture of brain activity (see Inventing electricity $\rightarrow$ Finding out that the internet exists $\rightarrow$ Really using the internet for what it's for! $\rightarrow$ Not to give out personal data with text on the poster).

The other group used a drastic approach, seizing the idea that anyone can impersonate anyone on the internet. In fact, the strong visuals reinforced the message and emphasized it. This poster is funny, eye-catching, and meaningful at the same time (see the poster "No one is what they seem" online).

Figure 2. Posters/memes created by workshop participants to promote internet awareness

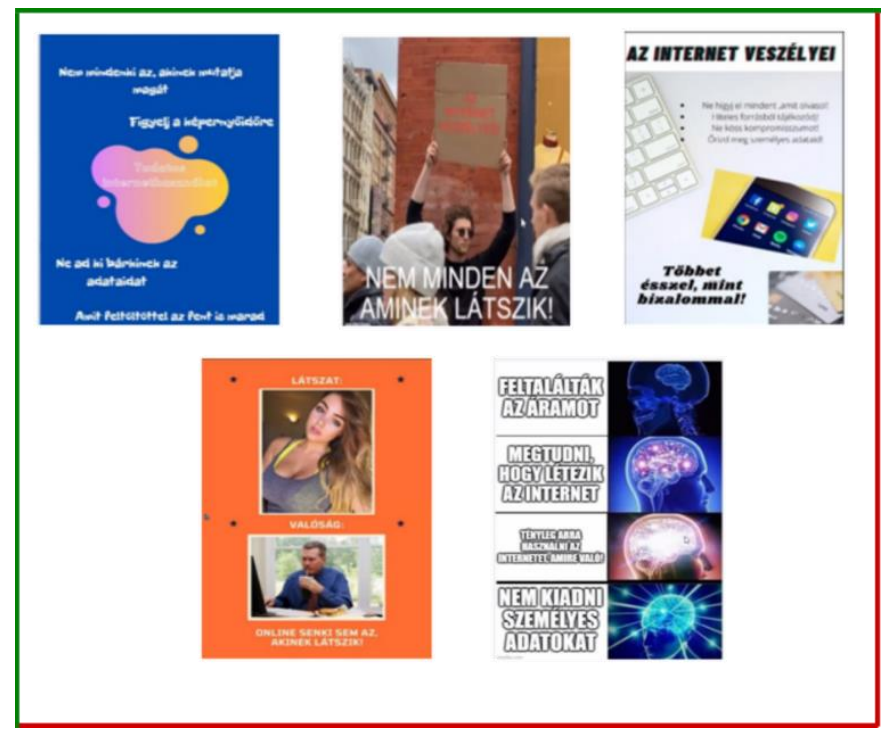

Source. The figure is published with the consent of the participating students. Language of the activity: Hungarian.

The students demonstrated the creativity of fairy tales in practice through a creative exercise. By making posters, students were able to visually capture the main messages and ideas about the dangers of the Internet. These are a very good illustration of how the session has achieved its purpose, as many aspects of the topic were covered, and by the end of the third session, many of the ideas on awareness had matured in the students. This is very well illustrated by the fact that the deception of the wolf was reflected upon in great detail, and even later on, a fairy tale example was brought in for an exercise where this was not explicitly asked for (not even mentioned as an option). The sessions were also enriched by playful exercises, all of which were introduced (sometimes directly, sometimes indirectly) in relation to the theme of conscious internet use. Feedback suggests that the majority of students enjoyed the sessions.

\section{Feedback from the Undergraduate Students}

Following each session, feedback can be grouped as follows:

- childhood nostalgia for fairy tales

- $\quad$ stories/tales that stimulate creativity and thinking

- $\quad$ enjoyable teaching, learning framework with fairy tales

- discovering the impact of fairy tales on self-awareness

- A childhood nostalgia for fairy tales:

"I really liked these stories. Especially because they brought back my childhood when my mother used to tell me these stories. I really liked it all, these 3 times. There are so many things that I think I will use in the future when I am a graduate teacher. So it was really positive for me." (3rd time, 4th participant, female, TTK)

"I really liked them too, and it was nice to feel nostalgic when you told the stories." (3rd time, 1st participant, male, BTK)

"For me, this duckling story was very good in the whole course. And so it was nice to hear from everyone how they would have finished their little story. So it was nice to get a glimpse into someone else's thinking. It was also nice to remember the story." (2nd time, 19th participant, female, BTK) 
- Stories/tales that stimulate creativity and thinking:

"I really liked it too, and it was creative and instructive how much you can get out of such a short story, and how many different tools and things you can illustrate." (1st time, 4th participant, female, TTK)

"I liked the class too, and mainly because it was interactive and we had to play and think, and that was good." (1st time, 22nd participant, male, GYTK)

"For me, too, it was an interesting experience of self-praise. The alternative ending to the story worked. It's actually one of the most fun assignments I've had this week. So I enjoyed it." (2nd time, 5th participant, male, BTK)

- An enjoyable educational, learning framework with fairy tales:

"I also liked the fact that we worked through the story together, and that we were involved in the whole hour, and it was not just an ordinary, everyday, boring performance." (1st time, 18th participant, female, BTK)

"I think it was also useful and exciting, because we were really involved, and we didn't just sit and listen to the material quietly, but we were involved and we sort of worked through the whole thing together." (1st time, 6th participant, female, BTK)

"I also really liked the fact that it was a different approach to what we are used to at university. And we stepped out of our comfort zone." (3rd time, 3rd participant, female, BTK)

- Exploring the impact of fairy tales on self-awareness:

"I really liked the fact that we covered more topics, and it wasn't just the monotony. It was varied, it was enriched with games. I also really liked this story. Also that there were exercises for ourselves. I'm thinking here of the last task. So I had a good time." (1st time, 17th participant, female, BTK)

"I also really liked the whole performance. Especially the proverbial part, and also the fairy tale framework, how much of our inner conflict can be resolved in a fairy tale. So for me, it was a very positive experience." (1st time, 19th participant, female, BTK)

"For me, this duckling story was very good in the whole course. And so it was nice to hear from everyone how they would have finished their little story. So it was nice to get a glimpse into someone else's thinking. It was also nice to remember the story." (3rd time, 16th participant, female, TTK)

"I also really enjoyed each of the sessions. And that we learned ways to get closer to children in a playful way. And also the stories, where they can live their own problems, maybe offering them solutions on how to deal with their own conflicts." (3rd time, 17th participant, female, BTK)

In addition to the above-mentioned experiences, we also value the feedback of the instructor. According to the trainer, the group cohesion increased and the bonds of trust within the community strengthened. This can be illustrated by the fact that there was more than one student who, during the joint discussion, presented examples from his/her own life, i.e. explicitly took on the personal and open character, even though this was not an particular request, and even when the presentation of personal experiences was not presented as an optional option. We agreed on confidentiality, respecting ethical rules, and at the same time agreed to anonymize our experiences in our thesis. For this reason, we have not disclosed the name of the instructor or any personal details of the group members.

\section{Summary}

This study explored the potential of the experimental application of Metamorphoses creativedevelopmental storytelling therapy embedded in higher education. The sessions were developed specifically for use online during the pandemic and reflected specifically on the givens and dangers of using the internet and the online environment. Overall, the feedback was positive and testified to the students' willingness to welcome sessions where self-reflection, as well as knowledge, is a part of the experience. Connecting to and with stories helped to bring to the surface a number of relevant issues and opportunities for improvement.

Based on the threats listed in relation to the internet, three main content themes emerged in the drafts: confidence, self-image, and self-representation - for which we sought stories that could be used in therapy. Throughout the sessions, the group successfully reflected on the main dangers associated with the internet, such as misuse of personal data, data theft, hiding behind 'facelessness', defamation, the nature of content subject to the likes, time spent in front of a screen, manipulation, difficulties in filtering out valid information etc., and thus brought to the fore the issues of conscious internet use. Not only did the feedback indicate the success of the sessions, but also the level of participation, the willingness to join in, and the active cooperation of the students (which was evident from the interactive exercises). The objectives outlined in the sessions were 
achieved, and this is faithfully reflected in the posters/memes produced and presented by the students (see Figure 2).

Conscious internet use is also important among university students, as $90 \%$ of 16-24-year-olds use the internet daily, according to Eurostat's 2016 surveys. To spend time in front of a screen consciously and productively, it is important to consider how purposeful and time-limited the use of the web is. As mentioned by students, non-conscious internet users are less reliable sources of information, may even be victims of manipulation, browse with insufficient care, and lack critical thinking. Closely related to the big data phenomenon is the fact that the internet, by remembering our search habits, tries to prioritize advertisements and other content related to our consumption preferences, mostly with manipulative intentions. We can guard against this by being aware.

Through the stories, in addition to self-awareness, students can also develop labor market skills related to the conscious use of the internet, which they may be able to use in the future. We also focused on internet security and privacy, how to be present on social media, and the role of the internet in marketing. The development of creativity, which is essential in self-marketing and building personal brand, was also achieved.

The students were interested to see how the challenges of the Internet and the stories were intertwined within the framework of the method. However, by the end of the third session, they were convinced that the traditional tools of fairy tales can also be used to reflect on modern phenomena such as the Internet. In any case, the dichotomy between modernity and tradition was perceived as a discrepancy at the beginning of the session. The exercises that challenged the age group worked well, and the different questions were inspiring and led to constructive discussions. Since some of the stories were already familiar to the students (e.g. The Ugly Duckling, The Wolf, and the Seven Little Goats), it was not by chance that they reflected on the nostalgia experience in their reflections, but the use of the familiar stories to reflect on the internet was a novelty, as they had never encountered them in this context. The period of more than two hours may have seemed relatively long, but the tasks kept the participants so busy that the time passed quickly. Some moments evoked deep experiences of self-awareness, but due to the need to respect competence limits, these overly sensitive individual stories were not worked with in-depth.

The stories are practical in terms of length, working with one story can fit into a lesson, but you can also plan longer or shorter work depending on the purpose of the session. This is an individual decision for the storyteller. We can distinguish the storytelling method from bibliotherapy in that, while in literary therapy, the individual conversation and the individual way of thinking are mostly based on the author's work and the way of thinking about it, whereas in story therapy the orienting character of the author's way of thinking can be discovered mostly in the case of fictional tales, since the authors of folk tales are unknown. Folk tales are characterized by a unified world view, and they address the universal human being because all the elements of a folk tale carry the same truth. There is also a difference between the two methods in that folk tales are mostly told in the so-called "one-world" way. However, in literary therapy, it is important to have an appropriate level of understanding for the reception of the works, since we can see the works as literary products, and the author's life story and position in society can also be taken into account in the case of a particular work, which can even be imprinted in a work (e.g: the reasons for choosing a spouse were different in the past than they are now since in the past the main concern was financial security).

Feedback also shows that the students enjoyed working with the stories, they found the sessions useful from a self-awareness point of view, the stories proved to be inspiring for thinking, while the reflection process also brought out individual perspectives and experiences of the students involved. Self-awareness work lasts a lifetime, which is why we believe that it should be addressed at university (even though the stories). Not only the individual stories but also the ideas expressed during the joint work had an impact on the participants, as the students were able to relate to them, i.e. they were inspired by each other and could learn from each other. Working with fairy tales can not only have a community-building role, as we could see during the sessions but there is also a place for sensitization in education, teaching new ways of thinking and new perspectives. The method can be used not only with students but also with different age groups. In the case of pre-school children, it is a good idea to choose stories that show as much of the world as possible, as children at this age are still discovering the world. In this age group, it is also worth linking the stories to physical modalities, so that the child can get to know his or her own body, identify with it and do something with it. In the lower grades, the focus is on developing positive personality traits, learning basic moral values, and taking responsibility for the created world. In the upper grades, stories should show many realities that resonate with students' lives (humananimal bond, friendship-alliance, connection, loyalty etc.). Here we can even work with failed fairy tale heroes, pseudo-heroes. This is good for the student to see what the hero is not doing right, i.e. to see a counterexample. 
In seventh to eighth grade, the theme of growing up, male-female roles can also be explored, and devil stories can be used as a drug prevention "tool". In secondary school, the theme of detachment from parents and finding one's own way is a significant one. Talking about "who I am" can also be interesting for this age group, as can talking about male-female roles through stories. At the same time, death, existential issues, hopelessness, failure, and loneliness can also be addressed. And for adults, any kind of story can be used that responds to life situations at different life stages (marriage, divorce, death, children moving away etc.) (Boldizsár, 2019).

Because of their IQ-independence, folktales can be used very well with people with lower education, they can help to start and open communication with people from any social group since the person can give an opinion about the story in itself, which gives us an idea of his or her own way of thinking and attitude towards the topic in the story, and can also give an opinion about himself or herself, for which the story can provide a contextual framework (crutch, guide). The specificity of the sessions was that none of the stories directly presented the theme of the internet, and therefore the storyteller had a greater responsibility to guide the collective thinking and individual reflection, as the students had to be oriented towards the theme.

Stories are always useful for self-knowledge work, whether we are working with what the hero does well or what he does not do well. In addition to the above, fairy tales can also be used for various developmental purposes (skill development, memory development, creativity development, development of abstraction skills, development of cognitive skills etc.). Harnessing the creativity-enhancing power of fairy tales can also be a useful development opportunity for a wide range of age groups other than undergraduate students, especially for primary/secondary school students. The story therapist can even formulate specific goals for a particular fairy tale, but when formulating the goals and selecting the fairy tales, it is essential to take the age group and the developmental level of the participants into account when planning the entire fairy tale activity. At the end of the sessions, the specificities of the Metamorphoses creative-development storytelling experience were discussed with the students in light of the practical exercises.

\section{References}

Beck, U. (1999). World risk society. Polity Press.

Boldizsár, I. (2013). Mesekalauz úton lévőknek. Életfordulók meséi. [A Storybook for People on the Road. Stories of Life's Turns]. Magvető.

Boldizsár, I. (2019). Meseterápia. Mesék a gyógyitásban és a mindennapokban. [Fairy Tale Therapy. Tales in Healing and Everyday Life.] Magvető.

Boldizsár, I. (2020). Boldizsár I.: Meseország valóban mindenkié, mi döntjük el, hogy kit/mit engedünk onnan magunkho. Article. Retrieved May 4, 2021, from https://konyvesmagazin.hu/friss/boldizsar_ildiko_meseorszag_mindenkie.html

Botsman, R. (2019). Kiben bizzunk? Hogyan kapcsol össze és választ szét bennünket a digitális fejlödés? [Who Should We Trust? How Does Digital Development Connect and Disconnect Us?]. Cser Kiadó.

Csányi, D., Simon, K., \& Tsík, S. (2016). Papirszínház módszertani kézikönyv. [Methodology Manual of Paper Theatre.] Csimota.

Dahlin, B. (2017). Rudolf Steiner: The Relevance of Waldorf Education. Springer International Publishing: Springer.

Dessewffy, T. (2019). Digitális szociológia: Szociológiai képzelet a digitális korban [Digital Sociology: Sociological Imagination in the Digital Age.]. Typotex.

Eurostat (2020). Frequency of internet use. Retrieved May 4, 2021, from https://ec.europa.eu/eurostat/databrowser/view/isoc_ci_ifp_fu/default/table?lang=en

Eurostat (2016). Individuals who used the internet on average at least once a week, by age group and level of formal education, EU-28. Retrieved May 5, 2021, from https://ec.europa.eu/eurostat/statisticsexplained/index.php?title=File\%3AIndividuals_who_used_the_internet_on_average_at_least_once_a_week\%2C_by _age_group_and_level_of_formal_education $\% 2 \mathrm{C} \_E U$ -

28\%2C_2016_(\%25_of_individuals).png\&fbclid=IwAR0tERWf5bbzDOOC0t0ATeB51cTg1XBWAfxJIggklaQccf LniSHtdI-uk6c

Giddens, A. (2008). Szociológia. [Sociology.] Osiris.

Hern, A. \& Solon, O. (2018). Facebook closed $583 \mathrm{~m}$ fake accounts in the first three months of 2018. The Guardian. Retrieved May 4, 2021, from https://www.theguardian.com/technology/2018/may/15/facebook-closed-583m-fakeaccounts-in-first-three-months-of-2018

Innes, S. \& Agócs, Í. (2014). Az internet olyan, mint a pocsolya. [The Internet Is Like a Puddle.] Kolibri.

Jenkins, H. (2006). Fans, bloggers, and gamers: Exploring participatory culture. New York University Press. 
Kádár, A. (2014). Mesepszichológia 2. Útravaló kényes nevelési helyzetekhez. [Fairy Tale Psychology 2. A Guide to Sensitive Parenting Situations.] Kulcslyuk.

Latour, B. (2010). Tarde's idea of quantification. In M. Candea (Eds.). The Social after Gabriel Tarde: Debates and Assessments. (pp. 145-162). Routledge.

Nepmese.hu. A farkas és a hét kecskegida c. népmese. [The Wolf and the Seven Little Goats.] https://www.nepmese.hu/mesetar/mesek/a-farkas-es-a-het-kecskegida

Mérö, L. (2019). Az ész segédigéi: A tudás és a nemtudás pszichológiája. [The Auxiliaries of Reason: The Psychology of Knowing and Not Knowing.] Tericum.

Montessori, M. (1912). The Montessori Method. Frederick A. Stokes Company.

Mező, K. (2017). A mese szerepe a kreativitás fejlődésében. [The Role of Fairy Tales in the Development of Creativity.] In Bujdosóné Papp, A. (Ed.) "A gyermeknek mese kell". A mese szerepe az óvodai és iskolai nevelésben. ["A Child Needs a Tale". The Role of Fairy Fales in Pre-School and School Education.](pp. 23-42.) Hagyományok Háza.

Nagy, O. (1974). Hösök, csalókák, ördögök. [Heroes, Tricksters, Devils.] Kriterion Kiadó.

Propp, V. J. (2005). A mese morfológiája [Morphology of the Fairy Tale]. (Translated: Soproni A.). Osiris.

Steiner, R. (1995). The Kingdom of Childhood. Introductory Talks on Waldorf Education. Anthroposophic Press. Hudson. Tari, A. (2019). Online illúziók-Offline valóság. [Online Illusions - Offline Reality]. Tericum.

Tari, A. (2010). Y generáció. [Generation Y]. Jaffa Kiadó.

Timárné Hunya, T. (2006). A népmese és a mümese sajátosságairól. [On the Characteristics of Folktales and Literary Fairy Tales] In Bálint, P. (Ed.). Közelitések a meséhez. Debreceni Egyetem: Didakt Kft.

Turi, T. (2020). \#maganelet. [\#Privatelife]. Jelenkor, irodalmi és müvészeti folyóirat, 68(2), 127

Acknowledgments: Furthermore, this work also utilizes the lessons learned in the 120-hour Metamorphoses creativedevelopmental fairy tale therapy training course, conducted by Ildikó Boldizsár, held between February 2020 and August 2020 , in which the author also participated.

We thank Johnathan Dabney for the English language editing.

(C) 2021 by the authors. Submitted for possible open access publication under the terms and conditions of the Creative Commons Attribution (CC BY) license (http://creativecommons.org/licenses/by/4.0/). 